\title{
Key biogeochemical factors affecting soil carbon storage in Posidonia meadows
}

\author{
Oscar Serrano $^{1,2}$, Aurora M. Ricart ${ }^{1,3}$, Paul S. Lavery ${ }^{1,4}$, Miguel Angel Mateo ${ }^{1,4}$, Ariane Arias-Ortiz ${ }^{5}$, \\ Pere Masque $^{1,2,5,6}$, Mohammad Rozaimi ${ }^{1,7}$, Andy Steven ${ }^{8}$, and Carlos M. Duarte ${ }^{9}$ \\ ${ }^{1}$ School of Sciences, Centre for Marine Ecosystems Research, Edith Cowan University, \\ Joondalup WA 6027, Australia \\ ${ }^{2}$ The University of Western Australia Oceans Institute, University of Western Australia, 35 Stirling Highway, \\ Crawley WA 6009, Australia \\ ${ }^{3}$ Departament d'Ecologia, Universitat de Barcelona, Av. Diagonal 643, 08028 Barcelona, Spain \\ ${ }^{4}$ Centro de Estudios Avanzados de Blanes, Consejo Superior de Investigaciones Científicas, 17300 Blanes, Spain \\ ${ }^{5}$ Departament de Física \& Institut de Ciència i Tecnologia Ambientals, Universitat Autònoma de Barcelona, \\ 08193 Bellaterra, Catalonia, Spain \\ ${ }^{6}$ School of Physics, the University of Western Australia, Crawley WA 6009, Australia \\ ${ }^{7}$ School of Environmental and Natural Resource Sciences, Faculty of Science and Technology, \\ Universiti Kebangsaan Malaysia, 43600 UKM Bangi, Selangor, Malaysia \\ ${ }^{8}$ CSIRO, EcoSciences Precinct, 41 Boggo Road, Dutton Park QLD 4102, Australia \\ ${ }^{9}$ Red Sea Research Center, King Abdullah University of Science and Technology, Thuwal 23955-6900, \\ Kingdom of Saudi Arabia
}

Correspondence to: Oscar Serrano (o.serranogras@ecu.edu.au)

Received: 15 October 2015 - Published in Biogeosciences Discuss.: 27 November 2015 Revised: 8 July 2016 - Accepted: 13 July 2016 - Published: 15 August 2016

\begin{abstract}
Biotic and abiotic factors influence the accumulation of organic carbon $\left(\mathrm{C}_{\mathrm{org}}\right)$ in seagrass ecosystems. We surveyed Posidonia sinuosa meadows growing in different water depths to assess the variability in the sources, stocks and accumulation rates of $\mathrm{C}_{\text {org }}$. We show that over the last 500 years, $P$. sinuosa meadows closer to the upper limit of distribution (at 2-4 $\mathrm{m}$ depth) accumulated 3- to 4-fold higher $\mathrm{C}_{\text {org }}$ stocks (averaging $6.3 \mathrm{~kg} \mathrm{C}_{\text {org }} \mathrm{m}^{-2}$ ) at 3- to 4-fold higher rates (12.8 $\mathrm{g} \mathrm{C}_{\text {org }} \mathrm{m}^{-2} \mathrm{yr}^{-1}$ ) compared to meadows closer to the deep limits of distribution (at $6-8 \mathrm{~m}$ depth; $1.8 \mathrm{~kg} \mathrm{C}_{\text {org }} \mathrm{m}^{-2}$ and $3.6 \mathrm{~g} \mathrm{C}_{\text {org }} \mathrm{m}^{-2} \mathrm{yr}^{-1}$ ). In shallower meadows, $\mathrm{C}_{\text {org }}$ stocks were mostly derived from seagrass detritus ( $88 \%$ in average) compared to meadows closer to the deep limit of distribution ( $45 \%$ on average). In addition, soil accumulation rates and fine-grained sediment content $(<0.125 \mathrm{~mm})$ in shallower meadows (2.0 $\mathrm{mm} \mathrm{yr}^{-1}$ and $9 \%$, respectively) were approximately 2-fold higher than in deeper meadows $\left(1.2 \mathrm{~mm} \mathrm{yr}^{-1}\right.$ and $5 \%$, respectively). The $\mathrm{C}_{\mathrm{org}}$ stocks and accumulation rates accumulated over the last 500 years in bare sediments
\end{abstract}

(0.6 $\mathrm{kg} \mathrm{C}_{\text {org }} \mathrm{m}^{-2}$ and $\left.1.2 \mathrm{~g} \mathrm{C}_{\text {org }} \mathrm{m}^{-2} \mathrm{yr}^{-1}\right)$ were 3 - to 11 -fold lower than in $P$. sinuosa meadows, while fine-grained sediment content $(1 \%)$ and seagrass detritus contribution to the $\mathrm{C}_{\text {org }}$ pool (20\%) were 8- and 3-fold lower than in Posidonia meadows, respectively. The patterns found support the hypothesis that $\mathrm{C}_{\text {org }}$ storage in seagrass soils is influenced by interactions of biological (e.g., meadow productivity, cover and density), chemical (e.g., recalcitrance of $\mathrm{C}_{\text {org }}$ stocks) and physical (e.g., hydrodynamic energy and soil accumulation rates) factors within the meadow. We conclude that there is a need to improve global estimates of seagrass carbon storage accounting for biogeochemical factors driving variability within habitats. 


\section{Introduction}

The recent focus on carbon trading has intensified the interest in quantifying the capability of a variety of ecosystems to store carbon, since carbon storage provides one means of valuing these ecosystems. The role of seagrass meadows in absorbing and storing carbon dioxide over centennial to millennial scales is being evaluated in the context of climate change mitigation (Fourqurean et al., 2012; Duarte et al., 2013). Seagrasses occupy only $0.1 \%$ of the ocean surface but are considered one of the largest carbon sinks worldwide (Duarte et al., 2005, 2010; Mcleod et al., 2011). Unlike terrestrial ecosystems, which store organic carbon $\left(\mathrm{C}_{\text {org }}\right)$ mainly in the living biomass, $\mathrm{C}_{\text {org }}$ stocks in seagrass meadows are mainly found in their soils, where it can accumulate over millennia (Mateo et al., 1997). The substrates where seagrasses grow meet the requirements for sediment to be considered a soil (Serrano et al., 2012), despite marine ecologists broadly referring to seagrass substrates as sediments (Kristensen and Rabenhorst, 2015).

Seagrasses encompass a wide variety of species across a range of depositional environments and water depths (Carruthers et al., 2007), and the variability in the soil $C_{\text {org }}$ stocks among seagrass habitats has been found to be high (up to 18-fold; Lavery et al., 2013). However, there has been a tendency to simplify regional and global estimates of $\mathrm{C}_{\text {org }}$ stocks in seagrass ecosystems from a very limited data set, based on few species and habitats (Nelleman et al., 2009; Fourqurean et al., 2012). Geomorphological settings (i.e., topography and hydrology), soil characteristics (e.g., mineralogy and texture) and biological features (e.g., primary production and remineralization rates) control soil $\mathrm{C}_{\mathrm{org}}$ storage in both terrestrial ecosystems (Amundson, 2001; De Deyn et al., 2008; Jonsson and Wardle, 2009) and in mangrove and tidal salt marshes (Donato et al., 2011; Adame et al., 2013; Ouyang and Lee, 2014). However, our understanding of the factors regulating this variability in seagrass meadows is limited (Nellemann et al., 2009; Duarte et al., 2010; Serrano et al., 2014).

Based on the terrestrial analogues and the limited research undertaken on seagrasses, it is likely that multiple factors may influence $\mathrm{C}_{\text {org }}$ storage within seagrass meadows, including biotic and abiotic factors acting in the water column, canopy and the soils. The seagrass itself may exert a primary control on $\mathrm{C}_{\text {org }}$ storage through its biomass, productivity and nutrient content (Lavery et al., 2013; Serrano et al., 2014; Miyajima et al., 2015), all of which are highly variable depending upon seagrass species and habitat conditions (Alcoverro et al., 1995; Collier et al., 2007). Seagrass density, biomass and productivity are strongly related to the underwater light penetration (Dennison, 1987; Duarte, 1991). Therefore, it can be expected that different irradiance regimes (and therefore depth) would influence the $\mathrm{C}_{\text {org }}$ storage capacity of seagrasses (Serrano et al., 2014).
Once $\mathrm{C}_{\text {org }}$ is buried in the soil, biotic and abiotic factors are likely to control the degree of $\mathrm{C}_{\text {org }}$ accumulation and preservation (Burdige, 2007). The rates of soil accumulation, the sediment structure and the biochemical composition of the organic matter buried may strongly influence $\mathrm{C}_{\text {org }}$ accumulation and preservation, and are highly variable among seagrass meadows (De Falco et al., 2000; Kennedy et al., 2010; Duarte et al., 2013). Soil accumulation may be a function of the seagrass canopy structure (De Falco et al., 2000; Gacia and Duarte, 2001; Peralta et al., 2008; Hendriks et al., 2010), the availability of suspended particles to settle outside of the water column and the production of biogenic carbonates within the meadow (De Falco et al., 2000; Mazarrasa et al., 2015). If the accumulated sediments are fine, then they are likely to enhance the preservation of $\mathrm{C}_{\text {org }}$ since they tend to limit oxygen exchange and redox potentials, which reduce remineralization (e.g., Keil and Hedges, 1993). In addition, finally, while both autochthonous (e.g., plant detritus and epiphytes) and allochthonous (e.g., seston and terrestrial matter) sources contribute to the $\mathrm{C}_{\text {org }}$ pool in seagrass soils (Kennedy et al., 2010), the proportion of seagrass-derived $C_{\text {org }}$ may be an important factor controlling $\mathrm{C}_{\text {org }}$ storage capacity. Seagrass tissues contain relatively high amounts of degradationresistant organic compounds (e.g., lignin and cellulose; Harrison, 1989; Klap et al., 2000; Torbatinejad et al., 2007; Burdige, 2007) compared to seston and algal detritus (Laursen et al., 1996), which are more prone to remineralization during early diagenesis (Henrichs, 1992).

From the above, it is clear that a large number of factors can potentially influence the stocks and accumulation rates of $\mathrm{C}_{\mathrm{org}}$ in seagrass meadows. Here we studied Posidonia sinuosa meadows across a depth gradient, aiming to highlight key biogeochemical factors affecting $\mathrm{C}_{\text {org }}$ storage in seagrass soils that need to be accounted for when attempting to produce regional or global estimates of $\mathrm{C}_{\text {org }}$ storage in seagrass meadows. Previous research at this site (Collier et al., 2007, 2008) showed significant variation in plant biomass and productivity, water quality and sediment biogeochemistry parameters across this depth gradient. Bare sediments were also sampled and studied in order to determine the "background" $\mathrm{C}_{\text {org }}$ stocks and fluxes in the absence of a seagrass meadow.

\section{Material and methods}

\subsection{Study site and sampling}

The study was conducted at Cockburn Sound in Western Australia (Fig. 1), in dense and monospecific P. sinuosa meadows across a significant depth gradient. Cockburn Sound is a sheltered marine embayment consisting of a deep central basin surrounded by shallow sand banks and seagrass meadows (Kendrick et al., 2002). Four vertical cores were sampled at four water depths in vegetated areas $(1.6,4,5.7$ and $8 \mathrm{~m}$ ), while a single core at $4 \mathrm{~m}$ water depth was col- 


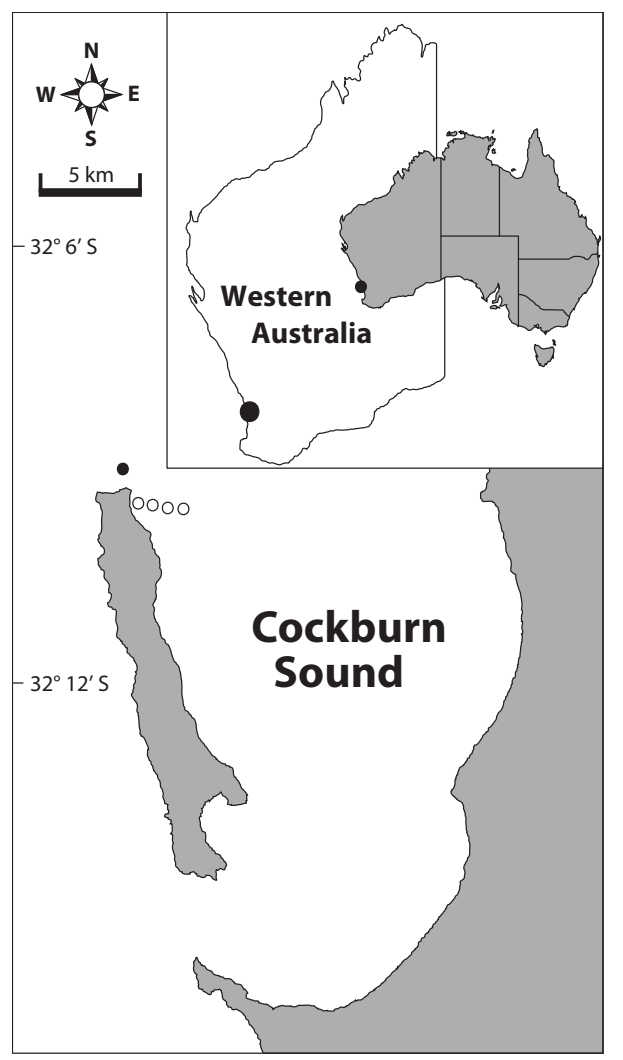

Figure 1. Location of the study sites, Cockburn Sound, Western Australia (Australia). White dot points represent the coring sites in seagrass $P$. sinuosa meadows at 2, 4, 6 and $8 \mathrm{~m}$ depth (from west to east). Bare sediment core is indicated by a black dot point.

lected from a bare area located at about $2 \mathrm{~km}$ distance from the nearest seagrass meadow. It was difficult or impossible to find a "pure control" (as per ecological definition) for this study. Shallow unconsolidated substrates in the study area should be occupied by seagrasses unless anthropogenic disturbances or hydrodynamic energy preclude so. In our case, the reference site was chosen based on the absence of seagrass at least since the 1960s (Kendrick et al., 2002), similar water depth $(4 \mathrm{~m})$, and the low likelihood of seagrass detritus from surrounding meadows being exported and accumulated in the area (Skene et al., 2005).

The core barrels consisted of PVC pipes $(65 \mathrm{~mm}$ inside diameter) with removable coring heads to cut fibrous material and minimize core shortening (compression) during coring (Serrano et al., 2012). The core barrels were driven into the soil by a hydraulic drill (LHD 23M, Atlas-Copco) that combined percussion and rotation. All cores were sealed at both ends, transported vertically to the laboratory and stored at $5^{\circ} \mathrm{C}$ before processing.

The lengths of soil recovered ranged from 57 to $123 \mathrm{~cm}$. Compression of loose soils during coring is an inevitable phenomenon and is routinely corrected by distributing the spatial discordances proportionally between the expected and the observed soil column layers (e.g., Glew et al., 2001). The overall degree of core shortening was low (less than $12 \%$ ) in all cases (corrected decompressed depths ranged from 65 to $134 \mathrm{~cm}$ ). The results reported in this study (i.e., density, soil accumulation rates and $\mathrm{C}_{\text {org }}$ stocks and accumulation rates) have been corrected for compression.

\subsection{Laboratory procedures}

The cores were cut longitudinally into two halves and sliced at regular intervals (i.e., $1 \mathrm{~cm}$ thick slices). Each slice/sample was weighed before and after oven drying to constant weight at $70^{\circ} \mathrm{C}(\mathrm{DW})$, and subsequently subdivided for analysis. The $\mathrm{C}_{\text {org }}$ elemental and isotopic composition of the organic matter was measured in milled subsamples from every second slice. These subsamples were acidified with $1 \mathrm{M} \mathrm{HCl}$, centrifuged (3500 RPM; 5 min) and the supernatant with acid residues was removed using a pipette, then washed in deionized water once, the residues were centrifuged again and the supernatant removed. The residual samples were re-dried $\left(70^{\circ} \mathrm{C}\right)$ before carbon elemental and isotopic analyses. Samples were acid-rinsed to ensure complete removal of inorganic carbon (i.e., carbonates) before $\mathrm{C}_{\mathrm{org}}$ analysis, despite the fact that this procedure may lead to an underestimation of soil $\mathrm{C}_{\text {org }}$ stocks (Phillips et al., 2011; Brodie et al., 2011). The $\mathrm{C}_{\text {org }}$ elemental and isotopic composition was also analyzed in P. sinuosa macro-detritus (i.e., sheaths, roots and rhizomes) collected at different depths along all seagrass cores for the carbon source study. The samples were washed in deionized water, dried at $70^{\circ} \mathrm{C}$ and encapsulated, and the $\mathrm{C}_{\text {org }}$ elemental and isotopic composition was analyzed using a Micro Cube elemental analyzer (Elementar Analysensysteme $\mathrm{GmbH}$, Hanau, Germany) interfaced with a PDZ Europa 20-20 isotope ratio mass spectrometer (Sercon Ltd., Cheshire, UK) at University California Davis facilities. The relative contents of $\mathrm{C}_{\text {org }}$ were calculated for the bulk (preacidified) samples. Carbon isotope ratios are expressed as $\delta$ values in parts per thousand (\%o) relative to VPDB (Vienna Pee Dee Belemnite).

For sediment grain-size analysis, a Mastersizer 2000 laserdiffraction particle analyzer was used following digestion of bulk samples with $10 \%$ hydrogen peroxide. Sediments were classified as coarse sand $(<1$ and $>0.5 \mathrm{~mm})$, medium sand $(<0.5$ and $>0.25 \mathrm{~mm})$, fine sand $(<0.25$ and $>0.125 \mathrm{~mm})$ and very fine sand plus mud $(<0.125 \mathrm{~mm})$.

\subsection{Age-depth chronology}

The age of the soil along the cores was determined combining ${ }^{210} \mathrm{~Pb}$ and $\mathrm{AMS}-{ }^{14} \mathrm{C}$ techniques for the recent (ca. $<100$ yr BP) and older (ca. <500 cal yr BP) material, respectively. Concentrations of ${ }^{210} \mathrm{~Pb}$ were determined by alpha spectrometry through the measurement of its granddaughter ${ }^{210} \mathrm{Po}$, assuming radioactive equilibrium between the two radionuclides (Sánchez-Cabeza et al., 1998). Between 150 and 
Table 1. Average \pm standard error (SE) density (in $\mathrm{g} \mathrm{cm}^{-3}$ ), $\mathrm{C}_{\mathrm{org}}$ content (in \%), $\delta^{13} \mathrm{C}$ signatures and sediment grain-size content at Cockburn Sound (normalized for ca. 500-year-old deposits).

\begin{tabular}{|c|c|c|c|c|c|c|c|c|c|c|c|c|c|c|}
\hline \multirow[b]{3}{*}{ Habitat } & \multirow{3}{*}{$\begin{array}{r}\text { Water } \\
\text { depth }(\mathrm{m})\end{array}$} & \multirow{3}{*}{$\begin{array}{r}\text { Thickness } \\
(\mathrm{cm})\end{array}$} & \multirow{3}{*}{$\begin{array}{r}\text { Age } \\
(\text { cal yr BP) }\end{array}$} & \multirow{2}{*}{\multicolumn{2}{|c|}{$\begin{array}{c}\text { Density } \\
\left(\mathrm{g} \mathrm{cm}^{-3}\right)\end{array}$}} & \multirow{2}{*}{\multicolumn{2}{|c|}{$\begin{array}{c}\mathrm{C}_{\mathrm{org}} \\
(\%)\end{array}$}} & \multirow{2}{*}{\multicolumn{2}{|c|}{$\begin{array}{c}\delta^{13} \mathrm{C} \\
(\% \circ)\end{array}$}} & \multicolumn{5}{|c|}{$\%$ sediment grain size $(\mathrm{mm})$} \\
\hline & & & & & & & & & & & $<0.125$ & $>0.125<0.25$ & $>0.25<0.5$ & $>0.5<1$ \\
\hline & & & & $\mathrm{N}$ & mean $\pm \mathrm{SE}$ & $\mathrm{N}$ & mean $\pm \mathrm{SE}$ & $\mathrm{N}$ & mean $\pm \mathrm{SE}$ & $\mathrm{N}$ & mean $\pm \mathrm{SE}$ & mean $\pm \mathrm{SE}$ & mean $\pm \mathrm{SE}$ & mean $\pm \mathrm{SE}$ \\
\hline \multirow[t]{4}{*}{ P. sinuosa } & 2 & 66 & 498 & 61 & $0.86 \pm 0.03$ & 31 & $1.28 \pm 0.22$ & 28 & $-11.6 \pm 0.2$ & 28 & $11 \pm 0.8$ & $43 \pm 1.0$ & $36 \pm 0.8$ & $9 \pm 0.9$ \\
\hline & 4 & 75 & 485 & 67 & $0.96 \pm 0.02$ & 34 & $1.06 \pm 0.16$ & 31 & $-12.2 \pm 0.3$ & 34 & $6 \pm 0.3$ & $47 \pm 1.0$ & $43 \pm 0.4$ & $5 \pm 0.6$ \\
\hline & 6 & 40 & 490 & 35 & $0.90 \pm 0.04$ & 18 & $0.59 \pm 0.15$ & 18 & $-13.9 \pm 0.4$ & 18 & $5 \pm 0.4$ & $44 \pm 0.9$ & $46 \pm 0.4$ & $5 \pm 0.5$ \\
\hline & 8 & 53 & 497 & 47 & $1.04 \pm 0.02$ & 24 & $0.38 \pm 0.10$ & 24 & $-16.2 \pm 0.4$ & 23 & $4 \pm 0.7$ & $43 \pm 0.7$ & $47 \pm 0.7$ & $6 \pm 0.5$ \\
\hline Bare & 4 & 75 & 490 & 70 & $1.22 \pm 0.02$ & 36 & $0.06 \pm 0.00$ & 36 & $-20.3 \pm 0.1$ & 36 & $1 \pm 0.2$ & $21 \pm 0.7$ & $51 \pm 0.2$ & $27 \pm 0.8$ \\
\hline
\end{tabular}

Table 2. (a) Results of one-way ANOVA on soil properties (normalized for ca. 500-year-old deposits). $P$ values correspond with those provided by the $f$ test. (b) Results of statistical testing (Tukey's HSD) for significant effects of water depth on the physicochemical parameters in the cores. Levels of significance are as follows: ${ }^{*} P<0.05 ;{ }^{* *} P<0.01 ;{ }^{* * *} P<0.001$; NS, $P \geq 0.05$.

\begin{tabular}{|c|c|c|c|c|c|}
\hline (a) & $\mathrm{d} f$ & SS & $F$ & $P$ & \\
\hline $\mathrm{C}_{\text {org }}(\%)$ & 4 & 5.16 & 36.28 & $<0.001$ & \\
\hline Error & 138 & 4.91 & & & \\
\hline$\delta^{13} \mathrm{C}(\% o)$ & 4 & 1610 & 210.90 & $<0.001$ & \\
\hline Error & 1320 & 252 & & & \\
\hline $\begin{array}{l}C_{\text {org stock }} \\
\left(\mathrm{g} \mathrm{C}_{\text {org cm}} \mathrm{cm}^{-3}\right)\end{array}$ & 4 & 39.98 & 40.16 & $<0.001$ & \\
\hline Error & 138 & 33.48 & & & \\
\hline$<0.125 \mathrm{~mm}(\%)$ & 4 & 25.49 & 60.99 & $<0.001$ & \\
\hline Error & 131 & 13.69 & & & \\
\hline (b) & & & $\mathrm{C}_{\mathrm{org}}(\%)$ & & \\
\hline$\delta^{13} \mathrm{C}(\% o)$ & $2 \mathrm{~m}$ & $4 \mathrm{~m}$ & $6 \mathrm{~m}$ & $8 \mathrm{~m}$ & Bare \\
\hline $2 \mathrm{~m}$ & & NS & $*$ & $* * *$ & $* * *$ \\
\hline $4 \mathrm{~m}$ & NS & & $*$ & $* * *$ & $* * *$ \\
\hline $6 \mathrm{~m}$ & $* * *$ & $* *$ & & NS & $* * *$ \\
\hline $8 \mathrm{~m}$ & $* * *$ & $* * *$ & $* * *$ & & $* * *$ \\
\hline \multirow[t]{2}{*}{ Bare } & $* * *$ & $* * *$ & $* * *$ & $* * *$ & \\
\hline & \multicolumn{5}{|c|}{$<0.125 \mathrm{~mm}(\%)$} \\
\hline $\begin{array}{l}C_{\text {org }} \text { stock } \\
\left(\mathrm{g} \mathrm{C}_{\text {org }} \mathrm{cm}^{-3}\right)\end{array}$ & $2 \mathrm{~m}$ & $4 \mathrm{~m}$ & $6 \mathrm{~m}$ & $8 \mathrm{~m}$ & Bare \\
\hline $2 \mathrm{~m}$ & & NS & $*$ & $* * *$ & $* * *$ \\
\hline $4 \mathrm{~m}$ & NS & & NS & NS & $* * *$ \\
\hline $6 \mathrm{~m}$ & $* *$ & $* *$ & & NS & $* * *$ \\
\hline $8 \mathrm{~m}$ & $* * *$ & $* * *$ & NS & & $* * *$ \\
\hline Bare & $* * *$ & $* * *$ & $* * *$ & $* * *$ & \\
\hline
\end{tabular}

$300 \mathrm{mg}$ aliquots of each sample were acid-digested after addition of ${ }^{209} \mathrm{Po}$ as spike and polonium isotopes were plated onto pure silver disks, and their alpha emissions were measured by alpha spectrometry. The concentrations of ${ }^{210} \mathrm{~Pb}$ at depths which were found to be constant were used to determine the average supported ${ }^{210} \mathrm{~Pb}$ concentrations, which were then used to obtain the concentrations of excess ${ }^{210} \mathrm{~Pb}$. A selection of samples of each core was measured for ${ }^{226} \mathrm{Ra}$ by gamma spectrometry to confirm the validity of the esti- mates of ${ }^{210} \mathrm{~Pb}$-supported values. Concentrations of ${ }^{226} \mathrm{Ra}$ were determined using a high-purity Ge well-type detector (CANBERRA, mod. GCW3523) through the $351 \mathrm{keV}$ emission line of ${ }^{210} \mathrm{~Pb}$.

For radiocarbon analyses, four samples of shells and one sample of $P$. sinuosa sheath remains were radiocarbon-dated at the National Ocean Sciences AMS Facility (Woods Hole Oceanographic Institution, Woods Hole, MA; Table A1 in Appendix A) following standard procedures (Stuiver and Pollack, 1977). Sheaths and shells were washed in ultrapure MQ water in order to remove fine sediment particles, examined under a stereomicroscope for lack of attached reworked materials and dried at $60^{\circ} \mathrm{C}$ before radiocarbon dating. The conventional radiocarbon ages were converted into calendar dates in years BP (cal yr BP) using the Calib 7.1 software (Marine13 curve), and the local marine reservoir effect due to the $\mathrm{C}$ dissolved in marine water was adjusted by deducting 71 years from the calibrated radiocarbon ages (Ulm, 2006). The calibrated ${ }^{14} \mathrm{C}$ ages corrected for the marine reservoir effect were used to produce an age-depth model (linear regression; present is 2012).

\subsection{Numerical procedures}

The $\mathrm{C}_{\text {org }}$ stocks per unit area $\left(\mathrm{kg} \mathrm{C}_{\mathrm{org}} \mathrm{m}^{-2}\right)$ were estimated by computing the cumulative mass of $\mathrm{C}_{\text {org }}$ accumulated over the last ca. 100 and 500 years (inventories in 13 to 30 and 40 to $75 \mathrm{~cm}$ thick deposits, respectively). The short- and longterm accumulation rates $\left(\mathrm{g} \mathrm{DW} \mathrm{m}^{-2} \mathrm{yr}^{-1}\right)$ of $\mathrm{C}_{\text {org }}$ were calculated by dividing the $\mathrm{C}_{\text {org }}$ inventories in the soil by the ages (for 100- and 500-year-old deposits, respectively). The decay rates of soil $\mathrm{C}_{\mathrm{org}}$ were calculated by fitting an exponential equation to the decreasing trends in $\mathrm{C}_{\text {org }}$ content $\left(\mathrm{mg} \mathrm{C}_{\mathrm{org}} \mathrm{cm}^{-3}\right)$ with aging. The data reported for seagrass soil properties at different water depths and bare sediments (Average \pm SE) were normalized for ca. 100- and/or 500year-old deposits (specified in each case).

A one-way ANOVA (analysis of variance) test was applied to test for any significant effect of water depth on the $\mathrm{C}_{\text {org }}$ elemental and isotopic composition, $\mathrm{C}_{\text {org }}$ stocks and accumulation rates and fine sediment content $(<0.125 \mathrm{~mm})$. When significant effects were detected, pairwise a posteriori comparisons were performed using a Tukey's HSD (honest significant difference) test. Data were fourth root transformed 
Table 3. Soil accumulation rates (SARs), $C_{\text {org }}$ accumulation rates and $C_{\text {org }}$ inventories in the seagrass cores studied (average \pm standard deviation). Estimates over short-term (derived from ${ }^{210} \mathrm{~Pb}$ dating, last 100 years) and long-term (derived from ${ }^{14} \mathrm{C}$ dating, last 500 ) periods are provided. The thicknesses of seagrass soils corresponding to 100 and 500 years are provided.

\begin{tabular}{|c|c|c|c|c|c|c|c|c|c|}
\hline \multirow[b]{3}{*}{ Habitat } & \multirow{2}{*}{$\begin{array}{r}\text { Water } \\
\text { depth }(\mathrm{m})\end{array}$} & \multicolumn{4}{|c|}{ Short-term (100 years) } & \multicolumn{4}{|c|}{ Long-term (500 years) } \\
\hline & & Thickness & Stock & SAR & $\mathrm{C}_{\text {org }}$ acc. rates & Thickness & Stock & SAR & $\mathrm{C}_{\text {org acc. rates }}$ \\
\hline & & $(\mathrm{cm})$ & $\left(\mathrm{kg} \mathrm{C}\right.$ org $\left.\mathrm{m}^{-2}\right)$ & $\left(\mathrm{mm} \mathrm{yr}^{-1}\right)$ & $\left(\mathrm{gC}_{\mathrm{org}} \mathrm{m}^{-2} \mathrm{yr}^{-1}\right)$ & $(\mathrm{cm})$ & $\left(\mathrm{kgC}_{\mathrm{org}} \mathrm{m}^{-2}\right)$ & $\left(\mathrm{mm} \mathrm{yr}^{-1}\right)$ & $\left(\mathrm{g} \mathrm{C}_{\mathrm{org}} \mathrm{m}^{-2} \mathrm{yr}^{-1}\right)$ \\
\hline \multirow[t]{4}{*}{ P. sinuosa } & 2 & 30 & 4.5 & $3.0 \pm 1.1$ & $44.9 \pm 6.5$ & 66 & 6.0 & $1.3 \pm 0.1$ & $12.1 \pm 0.6$ \\
\hline & 4 & 20 & 3.4 & $2.0 \pm 0.7$ & $34.3 \pm 7.1$ & 75 & 6.5 & $1.5 \pm 0.1$ & $13.5 \pm 0.7$ \\
\hline & 6 & 16 & 1.2 & $1.6 \pm 0.7$ & $11.8 \pm 3.5$ & 40 & 1.7 & $0.8 \pm 0.03$ & $3.5 \pm 0.1$ \\
\hline & 8 & 13 & 1.1 & $1.3 \pm 0.2$ & $11.4 \pm 1.0$ & 53 & 1.8 & $1.1 \pm 0.04$ & $3.7 \pm 0.1$ \\
\hline Bare & 4 & 16 & 0.1 & $1.6 \pm 1.8$ & $1.1 \pm 0.3$ & 75 & 0.6 & $1.5 \pm 0.1$ & $1.2 \pm 0.1$ \\
\hline
\end{tabular}

Table 4. (a) Stable carbon isotopic composition values $\left(\delta^{13} \mathrm{C}\right)$ of potential organic matter sources used for the different sources in the Bayesian mixing models. Data for $P$. sinuosa detritus (sheaths, roots and rhizomes) along the cores at 2, 4, 6 and $8 \mathrm{~m}$ water depth are presented. (b) Relative contributions of potential sources of organic carbon to soils of $P$. sinuosa meadows in different depths and bare sediment (over 500 years of accumulation) as modeled by SIAR. Mean and lower and upper $95 \%$ credible interval (CI95) for all the range of feasible solutions in each Bayesian mixing model.

\begin{tabular}{|c|c|c|c|c|c|c|}
\hline \multicolumn{7}{|l|}{ (a) } \\
\hline Source & $\mathrm{N}$ & mean & $\begin{array}{l}\delta^{13} \mathrm{C}(\% o) \\
\text { standard deviation }\end{array}$ & References & & \\
\hline P. sinuosa $2 \mathrm{~m}$ & 8 & -11.5 & 1.4 & this study & & \\
\hline P. sinuosa $4 \mathrm{~m}$ & 6 & -10.6 & 1.9 & this study & & \\
\hline P. sinuosa $6 \mathrm{~m}$ & 6 & -10.3 & 1.7 & this study & & \\
\hline P. sinuosa $8 \mathrm{~m}$ & 7 & -13.3 & 1.2 & this study & & \\
\hline Epiphytes & 6 & -15.9 & 0.4 & this study & & \\
\hline Macroalgae & 6 & -18.6 & 1.8 & this study & & \\
\hline Seston & 40 & -24.2 & 0.6 & Waite et al. (2007) & & \\
\hline \multicolumn{7}{|l|}{ (b) } \\
\hline \multirow[t]{2}{*}{ Habitat } & \multicolumn{2}{|c|}{ Posidonia sinuosa } & \multicolumn{2}{|c|}{ Macroalgae + epiphytes } & \multicolumn{2}{|c|}{ Seston } \\
\hline & mean & CI95 & mean & CI95 & mean & CI95 \\
\hline $2 \mathrm{~m}$ & 0.94 & $0.88-0.99$ & 0.04 & $0.00-0.09$ & 0.02 & $0.00-0.05$ \\
\hline $4 \mathrm{~m}$ & 0.83 & $0.70-0.90$ & 0.11 & $0.00-0.23$ & 0.06 & $0.00-0.12$ \\
\hline $6 \mathrm{~m}$ & 0.46 & $0.29-0.63$ & 0.35 & $0.01-0.64$ & 0.20 & $0.01-0.38$ \\
\hline $8 \mathrm{~m}$ & 0.43 & $0.20-0.65$ & 0.39 & $0.01-0.75$ & 0.18 & $0.01-0.34$ \\
\hline Bare & 0.20 & $0.11-0.31$ & 0.22 & $0.01-0.40$ & 0.58 & $0.48-0.69$ \\
\hline
\end{tabular}

to meet ANOVA assumptions. Pearson's correlation analysis was used to test for significant relationships among the variables studied.

The Bayesian mixing model SIAR 4.2 (Parnell et al., 2010) was used to estimate the contribution of potential sources to the sedimentary $\mathrm{C}_{\text {org }}$. The model was run with three sources (seagrass detritus, epiphytes/macroalgae and seston). Separate mixing models were computed for each core and for both 100 and 500 years of accumulation. The $\delta^{13} \mathrm{C}$ values for all sources were assumed to be constant for each core, except the $\delta^{13} \mathrm{C}$ signatures of seagrass detritus. Previous studies showed that the $\delta^{13} \mathrm{C}$ values of $P$. sinuosa varied along this depth gradient (Collier et al., 2008). To account for this variability in seagrass tissue $\delta^{13} \mathrm{C}$, the $\delta^{13} \mathrm{C}$ signatures of seagrass detritus measured directly in the seagrass detritus present in each core were used in the corresponding mixing model. Concentration dependence was incorporated into the model because elemental concentrations were different between sources (Phillips and Koch, 2002). We did not consider any fractionation with aging $(0 \pm 0 \%$ ) in the model because previous studies suggest small diagenetic shifts for $\delta^{13} \mathrm{C}$ during decomposition (Zieman et al., 1984; Mateo et al., 2010).

\section{Results}

The soil characteristics of the $P$. sinuosa meadows in Cockburn Sound changed significantly with soil depth (and thus age), starting as low-density, highly organic soils that turned 

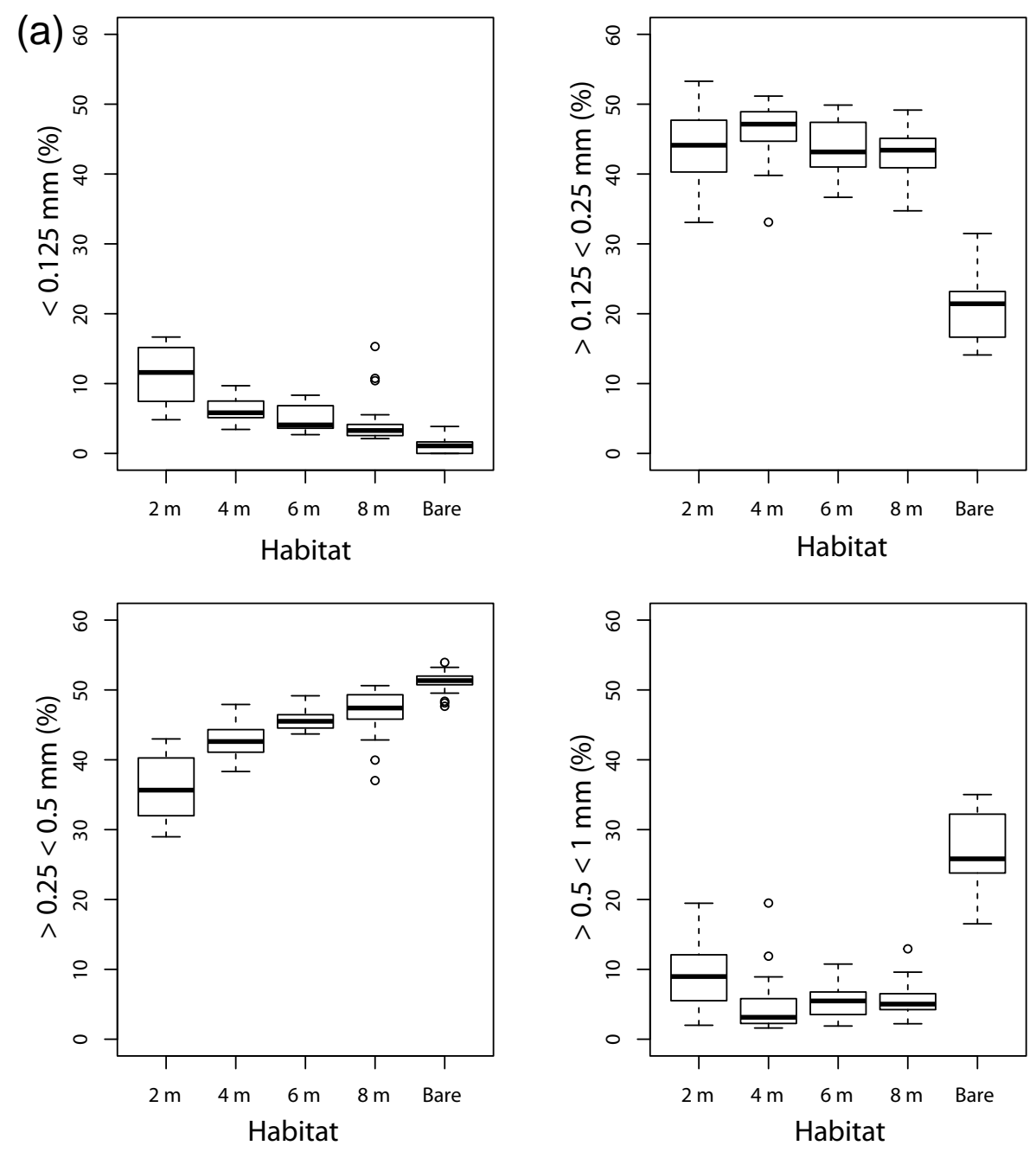

Figure 2.

into inorganic-dominated material $20 \mathrm{~cm}$ below the soil surface (after ca. 50 to 150 years of burial; Fig. A1 in Appendix A). Over 500 years of accumulation, soils in the $P$. sinuosa meadows closer to the upper limit of distribution (at 2 and $4 \mathrm{~m}$ depths) were significantly richer in $\mathrm{C}_{\text {org }}$ (mean \pm standard error of the mean $=1.2 \pm 0.2 \% \mathrm{C}_{\mathrm{org}}$ ) than those from deeper areas (at 6 and $8 \mathrm{~m}$ depths; $0.5 \pm 0.1 \%$ $\mathrm{C}_{\text {org }}$; Tables 1 and 2). The properties of the bare sediment core were homogeneous with depth/age (Fig. A1) and, on average, the $\mathrm{C}_{\text {org }}$ content was lower $(0.06 \%)$ and the density higher $\left(1.2 \mathrm{~g} \mathrm{~cm}^{-3}\right)$ compared to the vegetated cores (Tables 1 and 2). Medium and fine sands dominated in all seagrass cores ( $87 \%$ in average), while medium and coarse sands dominated in the bare sediment core (78\% in total; Table 1 and Fig. 2a). The proportion of fine grain-size material $(<0.125 \mathrm{~mm}$ ) increased from the bare core (averaging $1 \%)$ to $P$. sinuosa meadows closer to the deeper limit of distribution (4-5\% at 6 and $8 \mathrm{~m}$ depth) and meadows closer to the upper limit of distribution (6 to $11 \%$ at 2 and $4 \mathrm{~m}$ depth; Tables 1 and 2).

Concentration profiles of ${ }^{210} \mathrm{~Pb}$ showed decreasing trends from the surface down to depths of 10 to $16 \mathrm{~cm}$ (decompressed depths). The concentrations of ${ }^{226} \mathrm{Ra}$ (average: $0.4 \pm 2.1 \mathrm{~Bq} \mathrm{~kg}^{-1}$ ) were in agreement with those of ${ }^{210} \mathrm{~Pb}$ in the deepest sections of the cores, indicating absence of excess ${ }^{210} \mathrm{~Pb}\left({ }^{210} \mathrm{~Pb}\right.$ ex ; Fig. 3). All cores had similar concentrations of supported ${ }^{210} \mathrm{~Pb}\left(10.5 \pm 0.9 \mathrm{~Bq} \mathrm{~kg}^{-1}\right)$, whereas the ${ }^{210} \mathrm{~Pb}_{\text {ex }}$ inventories in the vegetated soils ranged from $427 \pm 45$ to $723 \pm 48 \mathrm{~Bq} \mathrm{~m}^{-2}$. Mixing of the upper soil layers was most severe in seagrass cores from the 2 and $6 \mathrm{~m}$ depth sites, where mixing was apparent in the top 3 and $7 \mathrm{~cm}$, respectively. Average short-term soil accumulation rates (SARs; ca. last 100 years) for each core were determined by applying the Constant Flux : Constant Sedimentation $(\mathrm{CF}: \mathrm{CS})$ model below the base of the mixed layer $(\mathrm{Kr}-$ ishnaswamy et al., 1971; Masqué et al., 2002; Fig. 3), ranging from $1.3 \pm 0.2$ to $3.0 \pm 1.1 \mathrm{~mm} \mathrm{yr}^{-1}$ (Table 3). Total ${ }^{210} \mathrm{~Pb}$ 


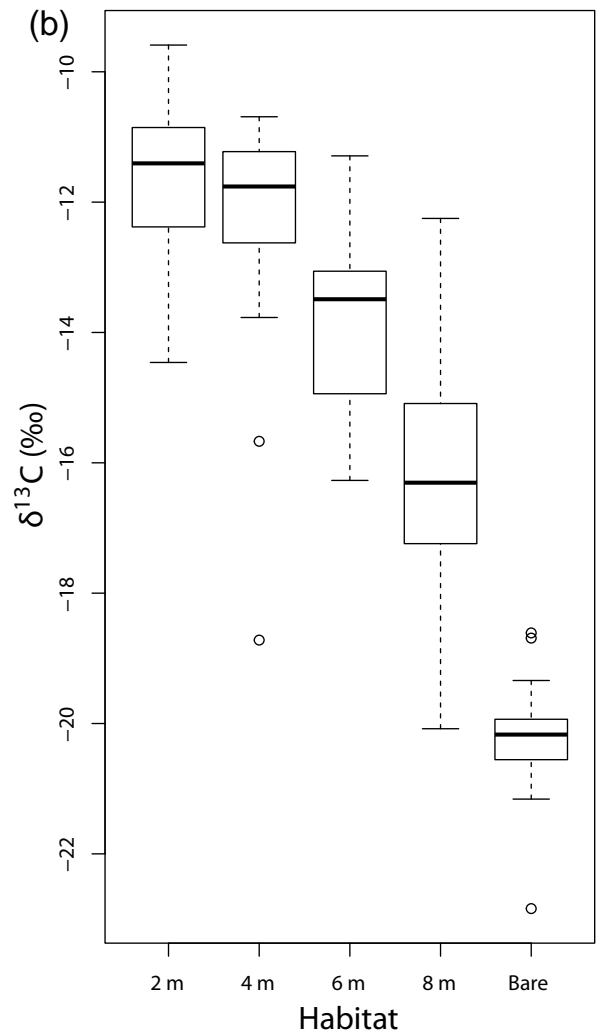

Figure 2. (a) Sediment grain-size contents in $P$. sinuosa meadows (at 2, 4, 6 and $8 \mathrm{~m}$ depth) and bare sediment cores (normalized for 500-year-old deposits) at Cockburn Sound; (b) $\delta^{13} \mathrm{C}$ signatures of the sedimentary organic carbon in $P$. sinuosa meadows (at 2, 4, 6 and $8 \mathrm{~m}$ depth) and bare sediment cores from Cockburn Sound (normalized for 500-year-old deposits). Box plot from top to bottom: largest observation, upper interquartile, median, lower interquartile and lowest observation.

concentrations measured in the reference core (i.e., bare sediment) were low $\left(10.1 \pm 1.2 \mathrm{~Bq} \mathrm{~kg}^{-1}\right)$ and not statistically different from the supported ${ }^{210} \mathrm{~Pb}$ concentrations measured in the $P$. sinuosa cores $\left(10.4 \pm 1.2 \mathrm{~Bq} \mathrm{~kg}^{-1}\right)$. The absence of excess ${ }^{210} \mathrm{~Pb}$ accumulation in bare sediment suggests negligible recent net accumulation of ${ }^{210} \mathrm{~Pb}$ (and thus sediments) in the absence of vegetation (i.e., last ca. 100 years). According to the age-depth models based on ${ }^{14} \mathrm{C}$ ages, long-term SARs (ca. last 500 cal yr BP) in $P$. sinuosa cores ranged from 0.8 to $1.3 \mathrm{~mm} \mathrm{yr}^{-1}$, while long-term SARs in bare sediments averaged $1.5 \mathrm{~mm} \mathrm{yr}^{-1}$ (Table 3).

Over 100 and 500 years of accumulation, the shallow $P$. sinuosa meadows (at 2 and $4 \mathrm{~m}$ depths) stored more carbon (averaging 4.0 and $6.3 \mathrm{~kg} \mathrm{C}_{\text {org }} \mathrm{m}^{-2}$, respectively) than the deeper counterparts at 6 and $8 \mathrm{~m}$ depths (1.2 and $1.8 \mathrm{~kg} \mathrm{C}_{\text {org }} \mathrm{m}^{-2}$, respectively; Table 3 and Fig. 4). The lowest $\mathrm{C}_{\mathrm{org}}$ inventories (500 years of accumulation; $0.6 \mathrm{~kg} \mathrm{C}_{\text {org }} \mathrm{m}^{-2}$ ) and accumulation rates (1.2 $\mathrm{g} \mathrm{C}_{\text {org }} \mathrm{m}^{-2} \mathrm{yr}^{-1}$ over 500 years) were found in the bare sediment core. The soil $\mathrm{C}_{\mathrm{org}}$ content $\left(\mathrm{mg} \mathrm{C}_{\mathrm{org}} \mathrm{cm}^{-3}\right)$ in

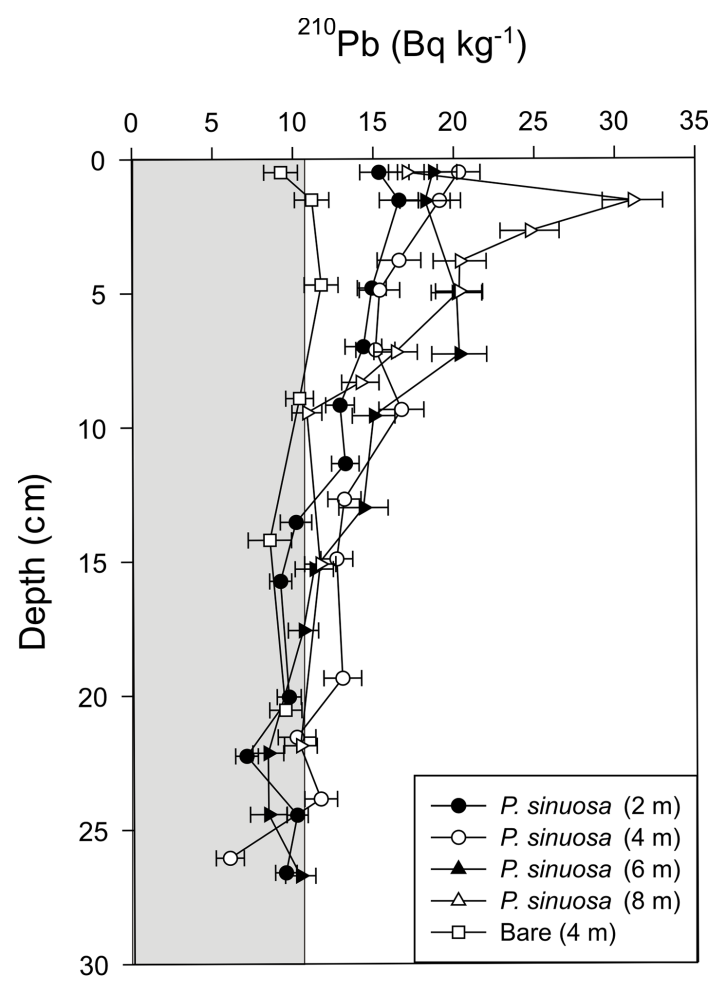

Figure 3. Concentration profiles of total and excess ${ }^{210} \mathrm{~Pb}$ in seagrass and bare sediment cores from Cockburn Sound. Gray shaded area indicates the concentration of supported ${ }^{210} \mathrm{~Pb}\left({ }^{210} \mathrm{~Pb}_{\text {sup }}\right)$.

the shallower meadows (at 2 and $4 \mathrm{~m}$ depth) decreased exponentially at rates of $0.0058 \pm 0.0012 \mathrm{yr}^{-1}(R=0.76)$ and $0.0043 \pm 0.0005 \mathrm{yr}^{-1}(R=0.86)$, respectively, while in meadows closer to the deeper limit of distribution (at 6 and $8 \mathrm{~m}$ depth $)$ it decreased at $0.0037 \pm 0.0014 \mathrm{yr}^{-1}(R=0.65)$ and $0.0085 \pm 0.0011 \mathrm{yr}^{-1}(R=0.92)$, respectively.

The $\delta^{13} \mathrm{C}$ values of sedimentary organic matter in soils from shallow meadows (at 2 and $4 \mathrm{~m}$ depths) were higher $(-12 \%)$ than those from the 6 and $8 \mathrm{~m}$ depths $(-14$ to $-16 \%$; Fig. 2b; Tables 1 and 2). Organic carbon in bare sediments was the most depleted in ${ }^{13} \mathrm{C}$ (overall mean - 20\%). Carbon isotopic ratios in extant seagrass tissues also varied between cores (Table 4a). On average, $\delta^{13} \mathrm{C}$ signatures of seagrass detritus preserved in the cores at 2,4 and $6 \mathrm{~m}$ water depth were ${ }^{13} \mathrm{C}$-enriched $(-10$ to $-11 \%$ o compared with those from $8 \mathrm{~m}$ depth $\left(-13 \%\right.$ ). The $\delta^{13} \mathrm{C}$ signatures of living epiphytes and macroalgae at Cockburn Sound averaged -16 and $-19 \%$, respectively (Table $4 a$ ).

The mixing models applied indicated that seagrass detritus was the most important source of soil $\mathrm{C}_{\text {org }}$ in all meadows studied (ranged from 43 to $94 \%$; Table $4 \mathrm{~b}$ ) over 500 years of accumulation, but its contribution decreased with water depth. In meadows closer to the upper limit of distribution (at 2 and $4 \mathrm{~m}$ depth), seagrass-derived detritus contributed 80 to $94 \%$ of the sedimentary $\mathrm{C}_{\text {org }}$, about 2 -fold higher than in deeper meadows (at 6 and $8 \mathrm{~m}$ depth; ranging from 43 


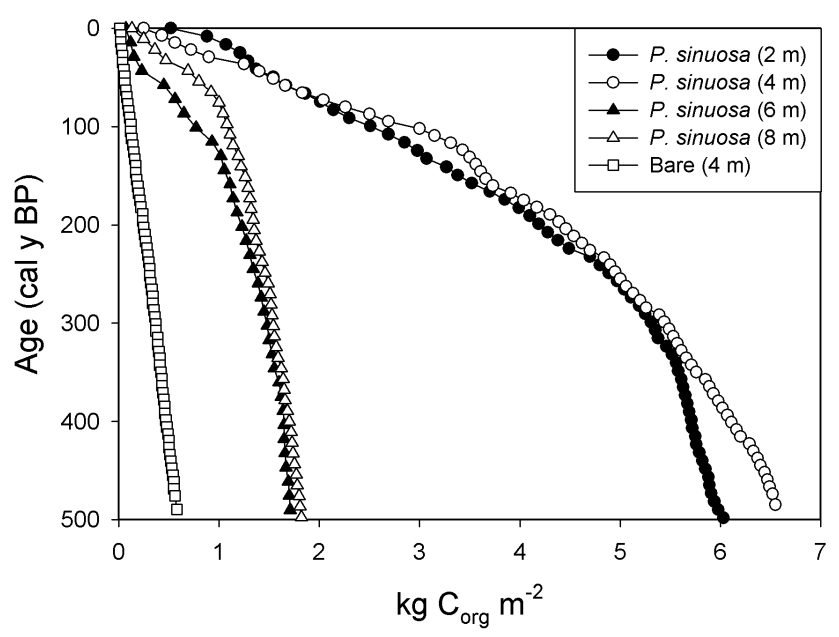

Figure 4. Inventories of $\mathrm{C}_{\mathrm{org}}\left(\mathrm{kg} \mathrm{C}_{\mathrm{org}} \mathrm{m}^{-2}\right)$ in $P$. sinuosa meadows (at 2, 4, 6 and $8 \mathrm{~m}$ depth) and bare sediments at Cockburn Sound (normalized for ca. 500-year-old deposits).

to $46 \%$ ). The contribution of epiphytes/macroalgae was 3to 10 -fold higher in deeper meadows (ranging from 35 to $39 \%$ ) compared to shallow meadows (4 to $11 \%$; Table $4 \mathrm{~b}$ ). The contribution of seston increased with depth, but was always less than the contributions from Posidonia and epiphytes/macroalgae (Table 4b). Bare sediments had the lowest seagrass contribution to the $\mathrm{C}_{\text {org }}$ pool and the highest proportion from seston (20 and $58 \%$, respectively; Table $4 \mathrm{~b}$ ).

Considering all soil layers from all cores, the $\mathrm{C}_{\text {org }}$ concentration increased with increasing fine sediment content $\left(r^{2}=0.52\right), \delta^{13} \mathrm{C}$ values $\left(r^{2}=0.33\right)$ and percentage contribution of seagrass detritus $\left(r^{2}=0.9\right.$; Fig 5). The $\delta^{13} \mathrm{C}$ signatures and \% particles $<0.125 \mathrm{~mm}$ were positively correlated $\left(r^{2}=0.57\right.$; Fig. 5).

\section{Discussion}

The results show a consistent decline in $\mathrm{C}_{\text {org }}$ stocks and accumulation rates with water depth in $P$. sinuosa meadows, where shallow meadows closer to the upper limit of distribution accumulated 3- to 4 -fold higher $\mathrm{C}_{\text {org }}$ stocks and at higher rates than those nearer the depth limits of distribution. We interpret the associated changes in biological (e.g., productivity, cover and density), chemical (e.g., recalcitrance of $\mathrm{C}_{\text {org }}$ stocks) and physical (e.g., hydrodynamic energy and SAR) factors within the meadows as evidence that the production, trapping and preservation of soil $\mathrm{C}_{\text {org }}$ in coastal areas are the result of complex interaction among all three sets of factors, as we represent in Fig. 6, and as is discussed below.

The findings from this study are consistent and complement earlier findings by Serrano et al. (2014). The analyses of new variables in the same cores (i.e., ${ }^{210} \mathrm{~Pb}$ dating, sediment grain-size, stable carbon isotopes in organic matter) provided new insights into the factors driving differences in
$\mathrm{C}_{\text {org }}$ storage along a depth gradient. We also compare the biogeochemical characteristics of seagrass soils with adjacent bare sediments. Differences in $\mathrm{C}_{\text {org }}$ stocks and accumulation rates between this and the previous study (Serrano et al., 2014) are related to the new age-depth models obtained in the cores (i.e., based on ${ }^{210} \mathrm{~Pb}$ dating). The results obtained lead us to conclude that in order to assess differences and compare $\mathrm{C}_{\text {org }}$ storage between seagrass habitats, it is recommended that $\mathrm{C}_{\text {org }}$ stocks be normalized by a period of accumulation (Rozaimi et al., 2016), rather than soil depth as commonly used (e.g., Serrano et al., 2014). Therefore, we present the results and develop the discussion according to the period of accumulation $\left({ }^{210} \mathrm{~Pb}\right.$-derived, short-term, last 100 years; and ${ }^{14} \mathrm{C}$-derived, long-term, last 500 years).

The results indicate that the $P$. sinuosa plants themselves play a key role in determining the amount of $\mathrm{C}_{\text {org }}$ available for burial along the depth gradient. It is well established that accumulation of $\mathrm{C}_{\text {org }}$ in sediments and soils is strongly affected by net primary production (Cao and Woodward, 1998; Serrano et al., 2014). The decline with depth of $\mathrm{C}_{\text {org }}$ stocks, $\mathrm{C}_{\text {org }}$ accumulation rates and seagrass-derived inputs into the sedimentary pool that we observed coincides with reduced seagrass abundance and production reported by Collier et al. (2007). These authors reported 18-24-fold reductions from shallow $(2 \mathrm{~m})$ to deep $(8 \mathrm{~m}) P$. sinuosa meadows in shoot density (from 1435 to 80 shoots $\mathrm{m}^{-2}$ ), aboveground biomass (from 899 to $47 \mathrm{~g} \mathrm{DW} \mathrm{m}^{-2}$ ) and belowground biomass (from 1028 to $43 \mathrm{~g} \mathrm{DW} \mathrm{m}^{-2}$ ) on the same depth gradient. Similar trends in meadow structure and productivity with depth have been found in other Posidonia meadows, linked to reductions in irradiance (West, 1990; Duarte, 1991; Mateo and Romero, 1997; Alcoverro et al., 2001; Olesen et al., 2002).

Relationships between water column depth, seagrass canopy structure and $\mathrm{C}_{\text {org }}$ stocks have been reported for Zostera muelleri and Halophila ovalis meadows (e.g., Samper-Villarreal et al., 2016). However, previous studies based their comparisons on soil thickness rather than $\mathrm{C}_{\mathrm{org}}$ accumulation rates (e.g., period of accumulation) and rely on the assumption that environmental gradients linked to e.g., anthropogenic disturbances remained constant over the period reconstructed. Seagrass meadow structure (e.g., density, cover, biomass) and even presence/absence can vary over seasonal, annual and decadal timescales, in particular for short-lived and highly dynamic meadows such as those formed by genera Zostera, Halophila and Halodule. The presence of a clear and stable environmental gradient (i.e., depth) over the last millennia (Skene et al., 2005), together with the presence of seagrass remains along the cores studied, provides further evidence for the relationships between biogeochemical factors and seagrass soil $\mathrm{C}_{\text {org }}$ storage reported in this study.

The higher SAR, fine-grained sediment contents and plant detritus inputs in meadows closer to the upper limit of distribution would contribute to higher accumulation and preser- 
(a)

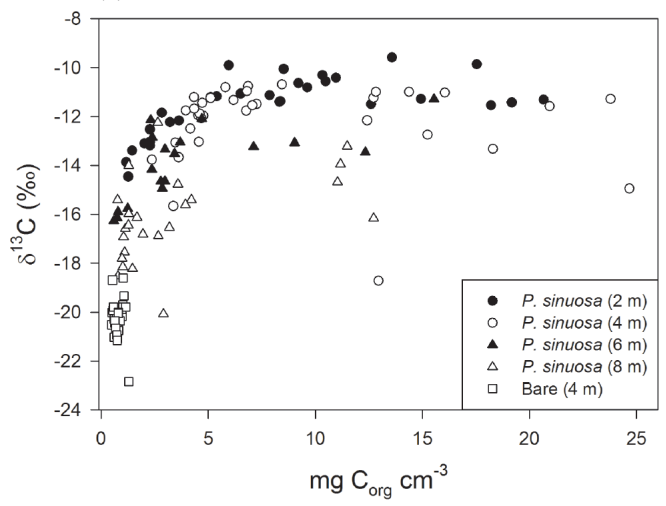

(c)

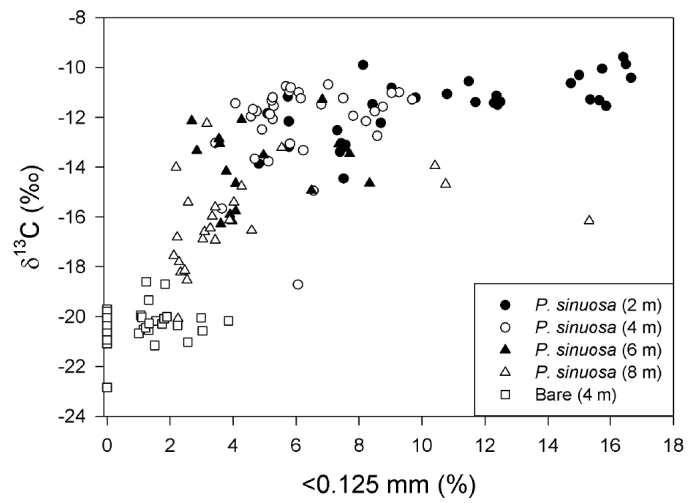

(b)

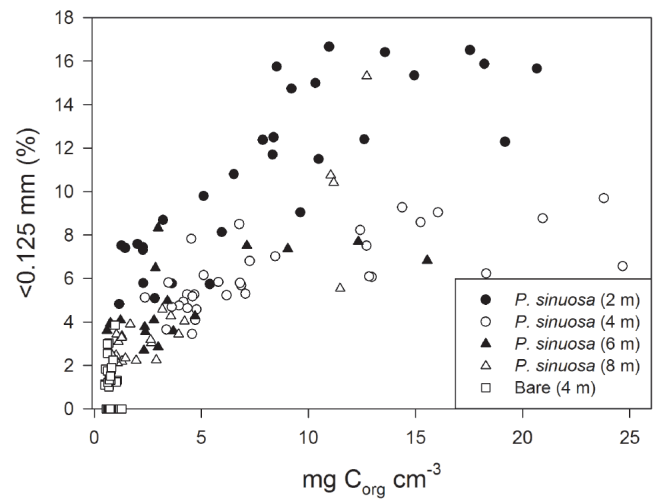

(d)

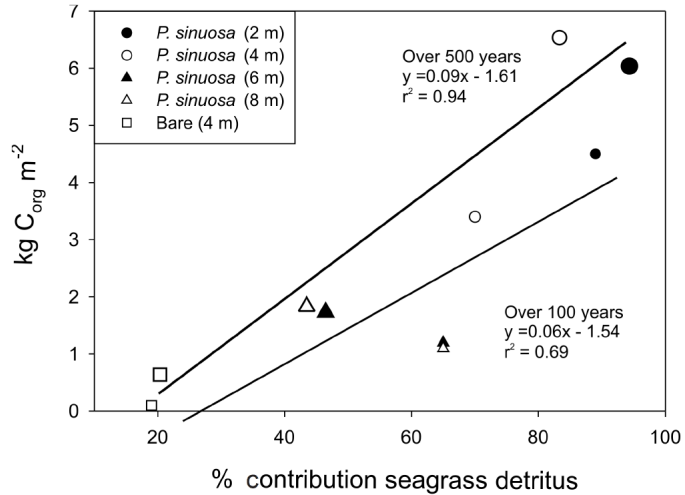

Figure 5. Biplots showing the relationships among the variables studied in the seagrass and bare sediment cores from Cockburn Sound (normalized for 500-year-old deposits). (a) $\delta^{13} \mathrm{C}$ signatures (\%o) plotted against $\mathrm{C}_{\text {org }}$ stocks $\left(\mathrm{mg} \mathrm{C}_{\text {org }} \mathrm{cm}^{-3}\right.$ ); (b) sediment grain size $<0.125 \mathrm{~mm}$ (\%) plotted against $\mathrm{C}_{\text {org }}$ stocks ( $\mathrm{mg} \mathrm{C}_{\text {org }} \mathrm{cm}^{-3}$ ); (c) $\delta^{13} \mathrm{C}$ signatures (\%o) plotted against sediment grain size $<0.125 \mathrm{~mm}(\%)$; and (d) contribution of seagrass detritus $(\%)$ plotted against soil $\mathrm{C}_{\mathrm{org}}$ stocks $\left(\mathrm{kg} \mathrm{C}_{\mathrm{org}} \mathrm{m}^{-2}\right.$, over 100 years - small symbols - and 500 years - big symbols - of accumulation).

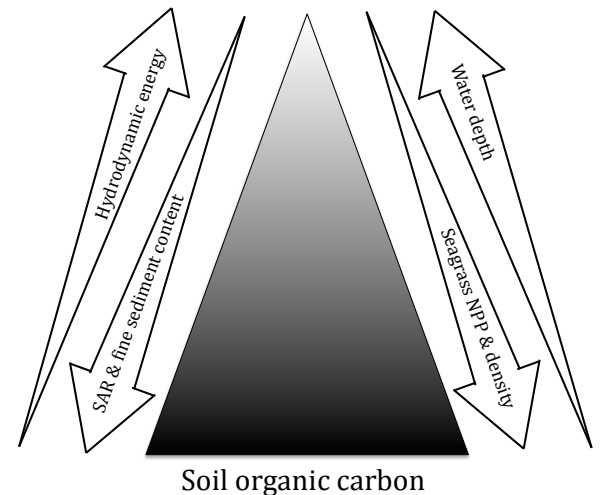

Figure 6. Influence of biogeochemical factors on the organic carbon storage capacity of seagrass ecosystems. Organic carbon in seagrass soil increases with high SAR, fine sediment content, seagrass NPP and density; and decreases with high hydrodynamic energy and water depth. SARs, soil accumulation rates; NPP, net primary production. vation of $\mathrm{C}_{\text {org }}$ after burial. The SAR in seagrass meadows is mainly controlled by the canopy structure, which affects the trapping and retention of sediment particles (Gacia and Duarte, 2001; Peralta et al., 2008; Hendriks et al., 2010), the hydrodynamic energy, the availability of fine-grained suspended particles in the water column and the production of biogenic carbonates within the meadow (De Falco et al., 2000, 2010; Mazarrasa et al., 2015). High plant biomass and density is associated with greater retention of particles (in particular, fine-grained sediments), lower hydrodynamic energy and higher production of biogenic carbonates within the meadow (De Falco et al., 2000), ultimately enhancing soil accumulation. The presence of a dense rhizome mat underlying shallow meadows may provide a positive feedback mechanism for enhanced SARs (i.e., presence of cavities reducing erosion and increasing soil accumulation; De Falco et al., 2000; Le Hir et al., 2007). The higher content of fine sediments we observed in shallow meadows would contribute to the higher $\mathrm{C}_{\text {org }}$ accumulation, since fine sediments generally retain more $\mathrm{C}_{\text {org }}$ compared to medium and coarse sands (Keil and Hedges, 1993; Burdige, 2007), and because rem- 
ineralization rates tend to be reduced in fine sediments due to lower oxygen exchange and redox potentials (Hedges and Keil, 1995; Dauwe et al., 2001; Burdige, 2007; Pedersen et al., 2011).

The differences in decay rates highlight different levels of $\mathrm{C}_{\text {org }}$ preservation in the different meadows. This is likely a result of both the sources of $\mathrm{C}_{\mathrm{org}}$ being buried and the biogeochemical conditions within the soils. Previous studies demonstrated that both autochthonous (e.g., seagrass and epiphyte detritus) and allochthonous (seston and terrestrial matter) sources contribute to the $\mathrm{C}_{\text {org }}$ pool in seagrass soils (50\% each on average; Kennedy et al., 2010). Here, we observed larger amounts of seagrass-derived $\mathrm{C}_{\text {org }}$ in shallow meadows (85\% in average), pointing to an important factor driving their higher $\mathrm{C}_{\text {org }}$ storage capacities compared to that of deeper meadows, namely the carbon preservation potential. Posidonia tissues contain relatively high amounts of degradation-resistant organic compounds in their tissues (e.g., lignin and cellulose; Harrison, 1989; Klap et al., 2000; Torbatinejad et al., 2007) and high $\mathrm{C} / \mathrm{N}$ ratios (Duarte, 1990; Pedersen et al., 2011; Kaal et al., 2016). In contrast, seston and algal detritus, which contributed as much as 64$75 \%$ of the $\mathrm{C}_{\text {org }}$ in the deeper sites, have a higher labile $\mathrm{C}_{\text {org }}$ content (Laursen et al., 1996) more likely to be remineralized during early diagenesis (Henrichs, 1992), potentially explaining the higher soil $\mathrm{C}_{\text {org }}$ decay rates in the deep (at $8 \mathrm{~m}$ ) $P$. sinuosa meadows. However, the soil $\mathrm{C}_{\mathrm{org}}$ decay rates in $P$. sinuosa meadows at $6 \mathrm{~m}$ depth were in the range of those found at 2 and $4 \mathrm{~m}$ depths. This may be due to the limitations of the approach used here. For example, we assumed that $\mathrm{C}_{\text {org }}$ inputs (i.e., quantity and quality) and decomposition have been constant during the period of accumulation under study, but this may not have been the case. Further, obtaining reliable estimates of $\mathrm{C}_{\text {org }}$ decay rates is also complicated by the presence of living biomass in the upper part of the soils, which is the case for the seagrass core sampled at $6 \mathrm{~m}$ depth, where fluctuations in the concentration of $\mathrm{C}_{\mathrm{org}}$ are evident.

The $\mathrm{C}_{\text {org }}$ decay rates of $P$. sinuosa meadows $\left(0.0056 \mathrm{yr}^{-1}\right.$ in average) are much higher than those reported for the similarly sized species $P$. oceanica (ranging from 0.00008 to $0.0005 \mathrm{yr}^{-1}$; Mateo et al., 1997; Serrano et al., 2012). This may contribute to the up to 16 -fold lower $\mathrm{C}_{\text {org }}$ stocks and accumulation rates in the soil beneath $P$. sinuosa compared to P. oceanica (Serrano et al., 2014).
Despite the limitations involved in using bare sediments as reference sites (e.g., inherent biogeochemical differences that preclude the settlement of seagrasses in bare sediments), the results suggest that $C_{\text {org }}$ stocks and accumulation rates are much higher in seagrass meadows than in adjacent bare sediments. The 3- to 11-fold lower $\mathrm{C}_{\text {org }}$ storage capacity of bare sediments compared to $P$. sinuosa meadows at comparable depths is mainly due to the absence of seagrass inputs. However, it may also result from the absence of a canopy that would otherwise enhance the trapping and retention of organic-rich, fine sediment particles (Hendriks et al., 2008), as reflected in the low content of fine-grained sediments. Since all continental margins store $\mathrm{C}_{\text {org }}$, there is a need to account for the net $\mathrm{C}_{\text {org }}$ storage capacity due to the presence of seagrasses when evaluating their role as carbon sinks.

The processes described in this study highlight the importance of meadow structure and productivity for $\mathrm{C}_{\text {org }}$ accumulation, supporting the hypothesis that the higher production of shallow meadows leads to higher accumulation rates of soil, fine-grained particles and seagrass detritus, which ultimately lead to the higher preservation and accumulation of $\mathrm{C}_{\text {org }}$. The relative importance of the biogeochemical factors identified in this study (e.g., hydrodynamic energy, sediment accumulation rates, fine sediment content, water depth, seagrass net primary production and density) in driving $\mathrm{C}_{\mathrm{org}}$ storage was not addressed, but rather we discussed the reasons why they can play a role in driving organic carbon storage and highlight potential synergistic and/or antagonistic interactions among them. Understanding the factors controlling $\mathrm{C}_{\text {org }}$ storage in seagrasses is at its onset, and a much better understanding is required before being able to disentangle the relative role/importance of each factor.

\section{Data availability}

Data supporting this study are available at Edith Cowan University Research Online portal. 


\section{Appendix A}

(a)

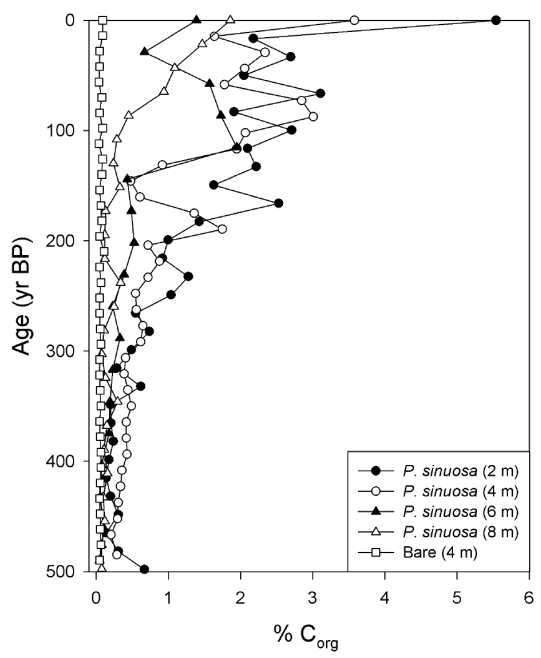

(c)

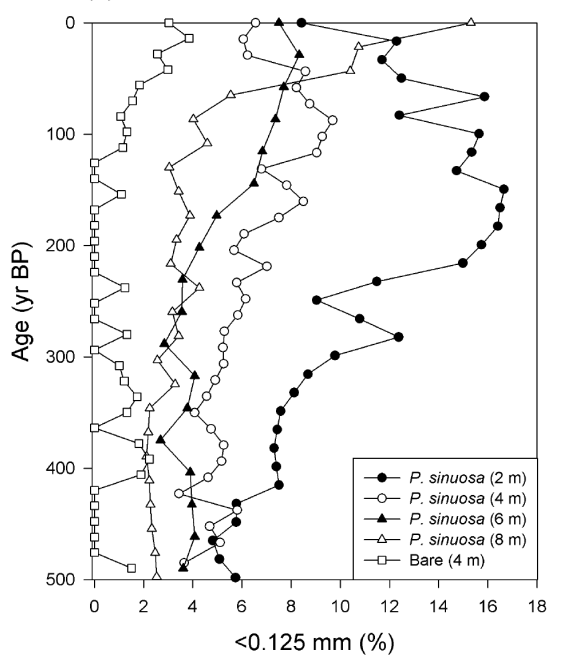

(b)

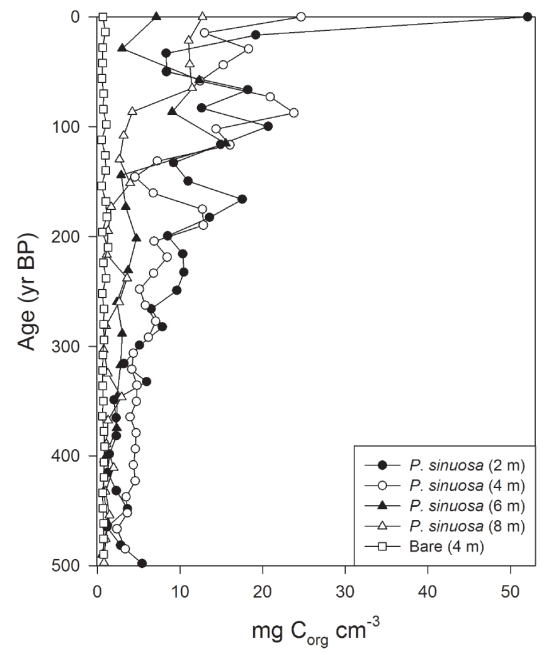

(d)

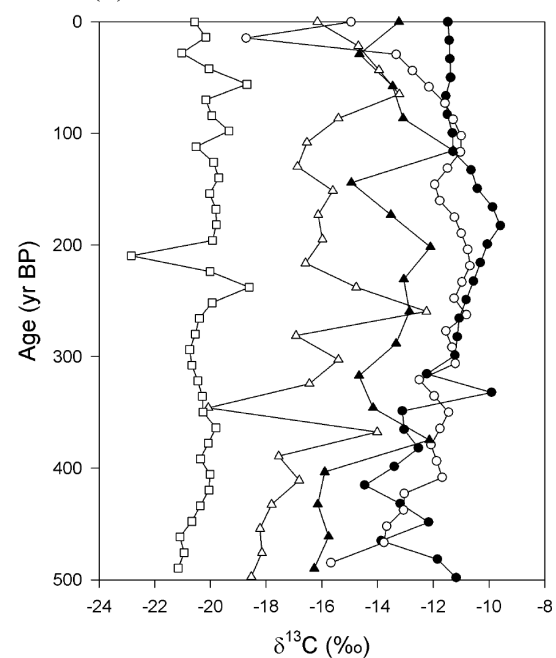

Figure A1. Substrate properties plotted against age at Cockburn Sound ( $P$. sinuosa cores at 2, 4, 6 and $8 \mathrm{~m}$ depth and bare sediment core at $4 \mathrm{~m}$ depth). (a) Organic carbon content (\%); (b) organic carbon stocks $\left(\mathrm{mg} \mathrm{Corg} \mathrm{cm}^{-3}\right)$; (c) sediment grain size $<0.125 \mathrm{~mm}$; (d) $\delta^{13} \mathrm{C}$ signatures $(\%)$ of organic carbon.

Table A1. Details of radiocarbon dating of the $P$. sinuosa sheaths and shells from the cores. The accession laboratory sample assigned by NOSAMS is indicated.

\begin{tabular}{lrrrrrr}
\hline Habitat & $\begin{array}{r}\text { Water } \\
\text { depth }(\mathrm{m})\end{array}$ & $\begin{array}{r}\text { Soil depth } \\
(\mathrm{cm})\end{array}$ & NOSAMS no. & $\begin{array}{r}\text { Raw age } \\
\text { (year BP })\end{array}$ & $\begin{array}{r}\text { Age error } \\
( \pm)\end{array}$ & Material \\
\hline P. sinuosa & 2 & 87 & 109170 & 803 & 25 & shell \\
& 4 & 79 & 109174 & 600 & 25 & sheath \\
& 6 & 64 & 109171 & 1020 & 20 & shell \\
& 8 & 97 & 109173 & 1120 & 20 & shell \\
bare & 4 & 75 & 109172 & 530 & 30 & shell \\
\hline
\end{tabular}


Acknowledgements. This work was supported by the ECU Faculty Research Grant Scheme, the ECU Early Career Research Grant Scheme and the CSIRO Flagship Marine \& Coastal Carbon Biogeochemical Cluster (Coastal Carbon Cluster) with funding from the CSIRO Flagship Collaboration Fund and the Generalitat de Catalunya (MERS, 2014 SGR-1356). Pere Masque was supported in part by a Gledden Visiting Fellowship awarded by the Institute of Advanced Studies at the University of Western Australia and AAO by a PhD grant of Obra Social "la Caixa". The authors are grateful to A. Gera, P. Bouvais and A. Esteban for their help in field and/or laboratory tasks.

Edited by: S. Bouillon

Reviewed by: two anonymous referees

\section{References}

Adame, M. F., Kauffman, J. B., Medina, I., Gamboa, J. N., Torres, O., Caamal J. P., Reza, M., and Herrera-Silveira, J.: Carbon stocks of tropical coastal wetlands within the karstic landscape of the Mexican Caribbean, PLoS ONE, 8 e56569, doi:10.1371/journal.pone.0056569, 2013.

Alcoverro, T., Duarte C. M., and Romero J.: Annual growth dynamics of Posidonia oceanica: Contribution of large-scale versus local factors to seasonality, Mar. Ecol.-Prog. Ser., 120, 203-210, 1995.

Alcoverro, T., Cebrian, E., and Ballesteros, E.: The photosynthetic capacity of the seagrass Posidonia oceanica: influence of nitrogen and light, J. Exp. Mar. Biol. Ecol., 261, 107-120, 2001.

Amundson, R.: The carbon budget in soils, Annu. Rev. Earth Pl. Sc., 29, 535-562, 2001.

Brodie, C. R., Leng, M. J., Casford, J. S. L., Kendrick, C. P., Lloyd, J. M., Yongqiang, Z., and Bird, M. I.: Evidence for bias in C and $\mathrm{N}$ concentrations and $\delta^{13} \mathrm{C}$ composition of terrestrial and aquatic organic materials due to pre-analysis acid preparation methods, Chem. Geol., 282, 67-83, 2011.

Burdige, D. J.: Preservation of Organic Matter in Marine Sediments: Controls, Mechanisms, and an Imbalance in Sediment Organic Carbon Budgets?, Chem. Rev., 107, 467-485, doi:10.1021/cr050347q, 2007.

Cao, M. and Woodward, N.: Net primary and ecosystem production and carbon stocks of terrestrial ecosystems and their responses to climate change, Glob. Change Biol., 4, 185-198, doi:10.1046/j.1365-2486.1998.00125.x, 1998.

Carruthers, T. J. B., Dennison, W. C., Kendrick, G. A., Waycott, M., Walker, D. I., and Cambridge, M. L.: Seagrasses of south-west Australia: A conceptual synthesis of the world's most diverse and extensive seagrass meadows, J. Exp. Mar. Biol. Ecol., 350, 2145, doi:10.1016/j.jembe.2007.05.036, 2007.

Collier, C. J., Lavery, P. S., Masini, R., and Ralph, P.: Morphological, growth and meadow characteristics of the seagrass Posidonia sinuosa along a depth-related gradient of light availability, Mar. Ecol.-Prog. Ser., 337, 103-115, doi:10.3354/meps337103, 2007.

Collier, C. J., Lavery, P. S., Masini, R. J., and Ralph, P.: Physiological characteristics of the seagrass Posidonia sinuosa along a depth-related gradient of light availability, Mar. Ecol.-Prog. Ser., 353, 65-79, 2008
Dauwe, B., Middelburg, J. J., and Herman, P. M. J.: Effect of oxygen on the degradability of organic matter in subtidal and intertidal sediments of the North Sea area, Mar. Ecol.-Prog. Ser., 215, 1322, 2001.

De Deyn, G. B., Cornelissen, J. H., and Bardgett, R. D.: Plant functional traits and soil carbon sequestration in contrasting biomes, Ecol. Lett. 11, 516-531, doi:10.1111/j.1461-0248.2008.01164.x, 2008.

De Falco, S., Ferrari, G., Cancemi, M., and Baroli, M.: Relationship between sediment distribution and Posidonia oceanica seagrass, Geo-Mar. Let., 20, 50-57, 2000.

De Falco, S., Tonielli, R., Di Martino, G., Innangi, S., Simeone, S., and Parnum, I. M.: Relationships between multibeam backscatter, sediment grain size and Posidonia oceanica seagrass distribution, Cont. Shelf Res., 30, 1941-1950, 2010.

Dennison, W. C.: Effects of light on seagrass photosynthesis, growth and depth distribution, Aquat. Bot., 27, 15-26, 1987.

Donato, D. C., Kauffman, J. B., Murdiyarso, D., Kurnianto, S., Stidham, M., and Kanninen, M.: Mangroves among the most carbon-rich forests in the tropics, Nat. Geosci., 4, 293-297, doi:10.1038/ngeo1123, 2011.

Duarte, C.: Seagrass nutrient content, Mar. Ecol.-Prog. Ser., 67, 201-207, 1990.

Duarte, C. M.: Seagrass depth limits, Aquat. Bot., 40, 363-377, 1991.

Duarte, C. M., Middelburg, J. J., and Caraco, N.: Major role of marine vegetation on the oceanic carbon cycle, Biogeosciences, 2, 1-8, doi:10.5194/bg-2-1-2005, 2005.

Duarte, C. M., Marbà, N., Gacia, E., Fourqurean, J. W., Beggins, J., Barrón, C., and Apostolaki, E. T.: Seagrass community metabolism: Assessing the carbon sink capacity of seagrass meadows, Global Biogeochem. Cy., 24, GB4032, doi:10.1029/2010GB003793, 2010.

Duarte, C. M., Losada, I., Hendriks, I., Mazarrasa, I., and Marbà, N.: The role of coastal plant communities for climate change mitigation and adaptation, Nature Climate Change, 3, 961-968, doi:10.1038/nclimate1970, 2013.

Fourqurean, J., Duarte, C., Kennedy, H., Marbà, N., Holmer, M., Mateo, M. A., Apostolaki, E. T., Kendrick, G. A., Krause-Jensen, D., McGlathery, K. J., and Serrano, O.: Seagrass ecosystems as a globally significant carbon stock, Nat. Geosci., 5, 1-7, doi:10.1038/NGEO1477, 2012.

Gacia, E. and Duarte, C. M.: Sediment Retention by a Mediterranean Posidonia oceanica Meadow: The Balance between Deposition and Resuspension, Estuar. Coast. Shelf Sci., 52, 505514, doi:10.1006/ecss.2000.0753, 2001.

Glew, J. R., Smol, J. P., and Last, W. M.: Sediment core collection and extrusion, in Tracking Environmental Change Using Lake Sediments, edited by: Last, W. M. and Smol, J. P., Kluwer Acad., Dordrecht, Netherlands, 73-105, 2001.

Harrison, P. G.: Detrital Processing in Seagrass Systems - a Review of Factors Affecting Decay-Rates, Remineralization and Detritivory, Aquat. Bot., 35, 263-288, doi:10.1016/03043770(89)90002-8, 1989.

Hedges, J. I. and Keil R. G.: Sedimentary organic matter preservation: An assessment and speculative synthesis, Mar. Chem., 49, 81-115, 1995.

Hendriks, I., Sintes, T., Bouma, T. J., and Duarte, C. M.: Experimental assessment and modeling evaluation of the effects of the 
seagrass Posidonia oceanica on flow and particle trapping, Mar. Ecol.-Prog. Ser., 356, 163-173, doi:10.3354/meps07316, 2008.

Hendriks, I. E., Bouma T. J., Morris E. P., and Duarte C. M.: Effects of seagrasses and algae of the Caulerpa family on hydrodynamics and particle-trapping rates, Mar. Biol., 157, 473-481, 2010.

Henrichs, S. M.: Early diagenesis of organic matter in marine sediments: progress and perplexity, Mar. Chem. 39, 119-149, 1992.

Jonsson, M. and Wardle D. A.: Structural equation modelling reveals plant-community drivers of carbon storage in boreal forest ecosystems, Biol. Lett., 6, 116-119, doi:10.1098/rsbl.2009.0613, 2009.

Kaal, J., Serrano, O., Nierop, K. G., Schellekens, J., Cortizas, A. M., and Mateo, M. Á.: Molecular composition of plant parts and sediment organic matter in a Mediterranean seagrass (Posidonia oceanica) mat, Aquat. Bot., 133, 50-61, 2016.

Keil, R. and Hedges J.: Sorption of organic matter to mineral surfaces and the preservation of organic matter in coastal marine sediments, Chem. Geol., 107, 385-388, 1993.

Kendrick, G. A., Aylward, M. J., Hegge, B. J., Cambridge, M. L., Hillman, K., Wyllie, A., and Lord, D. A.: Changes in seagrass coverage in Cockburn Sound, Western Australia between 1967 and 1999, Aquat. Bot., 73, 75-87, 2002.

Kennedy, H., Beggins, J., Duarte, C. M., Fourqurean, J. W., Holmer, M., Marba, N., and Middelburg, J. J.: Seagrass sediments as a global carbon sink: Isotopic constraints, Global Biogeochem. Cy., 24, GB4026, doi:10.1029/2010GB003848, 2010.

Klap, V. A., Hemminga, M. A., and Boon, J. J.: Retention of lignin in seagrasses: Angiosperms that returned to the sea, Mar. Ecol.Prog. Ser., 194, 1-11, doi:10.3354/meps194001, 2000.

Krishnaswamy, S., Lal, D., Martin, J., and Meybeck, M.: Geochronology of lake sediments, Earth Planet. Sc. Lett., 11, 407-414, 1971.

Kristensen, E. and Rabenhorst, M. C.: Do marine rooted plants grow in sediment or soil? A critical appraisal on definitions, methodology and communication, Earth-Sci. Rev., 145, 1-8, 2015.

Laursen, A. K., Mayer, L., and Townsend, D.: Lability of proteinaceous material in estuarine seston and subcellular fractions of phytoplankton, Mar. Ecol.-Prog. Ser., 136, 227-234, 1996.

Lavery, P. S., Mateo, M. A., Serrano, O., and Rozaimi, M.: Variability in the carbon storage of seagrass habitats and its implications for global estimates of blue carbon ecosystem service, PLoS One, 8, e73748, doi:10.1371/journal.pone.0073748, 2013.

Le Hir, P., Monbet, Y., and Orvain, F.: Sediment erodability in sediment transport modeling: can we account for biota effects?, Cont. Shelf Res., 27, 1116-1142, 2007.

Masqué, P., Isla, E., Sanchez-Cabeza, J. A., Palanques, A., Bruach, J. M., Puig, P., and Guillén, J.: Sediment accumulation rates and carbon fluxes to bottom sediments at Western Bransfield Strait basin (Antarctica), Deep-Sea Res. Pt. II, 49, 921-933, 2002.

Mateo, M. A. and Romero, J.: Detritus dynamics in the seagrass Posidonia oceanica: Elements for an ecosystem carbon and nutrient budget, Mar. Ecol. Ser., 151, 43-53, 1997.

Mateo, M. A., Romero, J., Pérez, M., Littler, M. M., and Littler, D. S.: Dynamics of Millenary Organic Deposits Resulting from the Growth of the Mediterranean Seagrass Posidonia oceanica, Estuar. Coast. Shelf Sci., 44, 103-110, 1997.

Mateo, M. Á., Renom, P., and Michener, R. H.: Long-term stability in the production of a NW Mediterranean Posidonia ocean- ica (L.) Delile meadow, Palaeogeogr. Palaeocl., 291, 286-296, doi:10.1016/j.palaeo.2010.03.001, 2010.

Mazarrasa, I., Marbà, N., Lovelock, C. E., Serrano, O., Lavery, P. S., Fourqurean, J. W., Kennedy, H., Mateo, M. A., Krause-Jensen, D., Steven, A. D. L., and Duarte, C. M.: Seagrass meadows as a globally significant carbonate reservoir, Biogeosciences, 12, 4993-5003, doi:10.5194/bg-12-4993-2015, 2015.

Mcleod, E., Chmura, G. L., Bouillon, S., Salm, R., Björk, M., Duarte, C. M., Lovelock, C. E., Schlesinger, W. H., and Silliman, B. R.: A blueprint for blue carbon: toward an improved understanding of the role of vegetated coastal habitats in sequestering $\mathrm{CO}_{2}$, Front. Ecol. Environ., 9, 552-560, doi:10.1890/110004, 2011.

Miyajima, T., Hori, M., Hamaguchi, M., Shimabukuro, H., Adachi, H., Yamano, H., and Nakaoka, M.: Geographic variability in organic carbon stock and accumulation rate in sediments of East and Southeast Asian seagrass meadows, Global Biogeochem. Cy., 29, 397-415, doi:10.1002/2014GB004979, 2015.

Nellemann, C., Corcoran, E., Duarte, C., Valdés, L., DeYoung, C., Fonseca, L., and Grimsditch, G. (Eds.): Blue carbon. A rapid response assessment, United Nations Environ. Program., GRIDArendal, www.grida.no, 2009.

Olesen, B., Enríquez, S., Duarte, C., and Sand-Jensen K.: Depthacclimation of photosynthesis, morphology and demography of Posidonia oceanica and Cymodocea nodosa in the Spanish Mediterranean Sea, Mar. Ecol.-Prog. Ser., 236, 89-97, 2002.

Ouyang, X. and Lee, S. Y.: Updated estimates of carbon accumulation rates in coastal marsh sediments, Biogeosciences, 11, 50575071, doi:10.5194/bg-11-5057-2014, 2014.

Parnell, A. C., Inger, R., Bearhop, S., and Jackson, A. L.: Source partitioning using stable isotopes: coping with too much variation, PLoS One, 5, e9672, doi:10.1371/journal.pone.0009672, 2010.

Pedersen, M. Ø., Serrano O., Mateo M. A., and Holmer M.: Decomposition of Posidonia oceanica matte in a climate change setting, Aquat. Microb. Ecol., 65, 169-182, 2011.

Peralta, G., Van Duren, L. A., Morris, E. P., and Bouma, T. J.: Consequences of shoot density and stiffness for ecosystem engineering by benthic marcrophytes in flow dominated areas: a hydrodynamic flume study, Mar. Ecol.-Prog. Ser., 368, 103-115, 2008.

Phillips, D. and Koch, P.: Incorporating concentration dependence in stable isotope mixing models, Oecologia, 114-125, doi:10.1007/s004420100786, 2002.

Phillips, S. C., Johnson, J. E., Miranda, E., and Disenhof, C. Improving CHN measurements in carbonate-rich marine sediments, Limnol. Oceanogr.-Meth., 9, 194-203, 2011.

Rozaimi, M., Lavery, P. S., Serrano, O., and Kyrwood, D.: Longterm carbon storage and its recent loss in an estuarine Posidonia australis meadow (Albany, Western Australia), Estuar. Coast. Shelf S., 171, 58-65, 2016.

Samper-Villarreal, J., Lovelock, C. E., Saunders, M. I., Roelfsema, C., and Mumby, P. J.: Organic carbon in seagrass sediments is influenced by seagrass canopy complexity, turbidity, wave height, and water depth, Limnol. Oceanogr., 61, 938-952, 2016.

Sanchez-Cabeza, J. A., Masqué, P., and Ani-Ragolta, I.: 210Pb and $210 \mathrm{Po}$ analysis in sediments and soils by microwave acid digestion, J. Radioanal. Nucl. Chem., 227, 19-22, 1998. 
Serrano, O., Mateo, M. A., Renom P., and Julià R.: Characterization of soils beneath a Posidonia oceanica meadow, Geoderma, 185186, 26-36, 2012.

Serrano, O., Lavery, P. S., Rozaimi, M., and Mateo, M. A.: Influence of water depth on the carbon sequestration capacity of seagrasses, Global Biogeochem. Cy., 301-314, doi:10.1002/2014GB004872, 2014.

Serrano, O., Ricart, A. M., Lavery, P. S., Mateo, M., AriasOrtiz, A., Masque, P., Steven, A., and Duarte, C. M.: Key Biogeochemical Factors Affecting Soil Carbon Storage in Posidonia Meadows [dataset], Edith Cowan University, doi:10.4225/75/56b2fd48b92d5, 2016.

Skene, D., Ryan, D., Brooke, B., Smith, J., and Radke, L.: The Geomorphology and Sediments of Cockburn Sound, Geoscience Australia, Record 2005/10, 2005.

Stuiver, M. and Pollack, H. A.: Discussion reporting C-14 data, Radiocarbon, 19, 355-363, 1977.
Torbatinejad, N. M., Annison, G., Rutherfurd-Markwick, K., and Sabine, J. R.: Structural constituents of the seagrass Posidonia australis, J. Agric. Food Chem., 55, 4021-4026, doi:10.1021/jf063061a, 2007.

Ulm, S.: Australian marine reservoir effects: A guide to $\Delta \mathrm{R}$ values, Austral. Archaeol., 63, 57-60, 2006.

Waite, M., Muhling, B., Holl, C. M., Beckley, L. E., Montoya, J. P., Strzelecki, J., Thompson, P., and Pesant, S.: Food web structure in two counter-rotating eddies based on $\delta^{15} \mathrm{~N}$ and $\delta^{13} \mathrm{C}$ isotopic analyses, Deep-Res. Pt. II, 54, 1055-1075, 2007.

West, R. J.: Depth-related structural and morphological variations in an Australian Posidonia seagrass bed, Aquat. Bot., 36, 153-166, 1990.

Zieman, J., Macko, S., and Mills, A.: Role of seagrasses and mangroves in estuarine food webs: temporal and spatial changes in stable isotope composition and amino acid content during decomposition, B. Mar. Sci., 35, 380-392, 1984. 